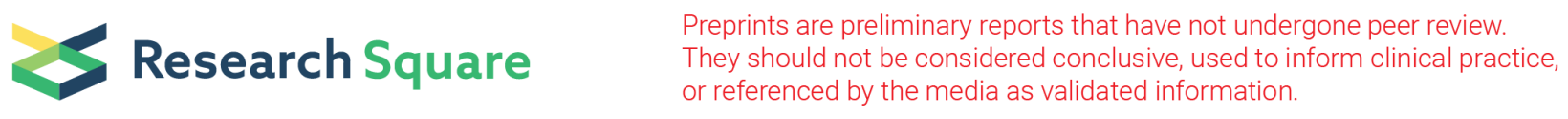

\title{
Flaws of universal salt iodization programmes in nutrition transition contexts: is there a risk of a double burden of inadequate iodine intake and excess adiposity? A case study in Tunisia
}

\author{
Radhouene DOGGUI ( $\nabla$ doggui.radhouene@gmail.com ) \\ Universite de Sherbrooke https://orcid.org/0000-0002-3539-8341 \\ Myriam El Ati-Hellal \\ Institut Preparatoire aux Etudes Scientifiques et Techniques \\ Jalila El Ati \\ Institut National de Nutrition et de Technologie Alimentaire \\ Pierre Traissac \\ Institut de recherche pour le developpement
}

\section{Research article}

Keywords: Double burden; lodine; Overweight/obesity; Salt consumption; Nutrition transition; Middle East and North Africa.

Posted Date: July 14th, 2020

DOI: https://doi.org/10.21203/rs.3.rs-40301/v1

License: (c) (1) This work is licensed under a Creative Commons Attribution 4.0 International License. Read Full License 


\section{Abstract}

Background In the Middle East and North Africa (MENA) region, universal salt iodization (USI) programs defaults were sometimes shown to increase the risk of iodine excess. Also, the nutrition transition which underlies the obesity epidemic in the MENA region is characterized by salt-rich diets, so that there could be a cumulative effect with respect to iodine status. We assess the within-subject co-existence of overweight and inadequate iodine intake, and associated factors.

Methods A national cross-sectional study used a stratified, clustered random sample and conducted among Tunisian school-age children aged from 6 to $12 \mathrm{y}$. $(n=1560)$. Overweight (OW) was body mass index (BMI)-for-age $\geq+1 z$. lodine deficiency was UIC (Urinary lodine Content) $<100 \mu g / L$ and iodine intake above requirements (IAR) UIC $\geq 200 \mu \mathrm{g} / \mathrm{L}$. Association of covariables with the within-subject double burden Ow-IAR was assessed by multinomial regression.

Results The prevalences of Ow-ID or Obe-ID were marginal, but not so for excess adiposity and IAR as for example prevalence of Ow-IAR was $9.8 \%$ ( $95 \%$ Cl: [7.7-12.3]). OW and IAR were found to co-occur independently $(P=0.29)$. Socio-economic patterning of Ow-IAR was mild. Nevertheless, prevalence were the lowest among children of mother with no formal schooling and in the South-East region. Beyond school-age children, we estimated that this double burden of overweight and excess iodine could concern a third of Tunisian adults (all the more for women).

Conclusions Among Tunisian children, iodine deficiency coupled with excess adiposity was quite marginal. Coexistence of overweight and excess iodine may affect a tenth of these children. More data would be needed to document a possibly even higher rate among adults. Cumulative effects of unhealthy lifestyle due to the nutrition transition interacting with metabolic pathways may be involved in this potential overweight-high iodine intake double burden. In the MENA region, obesity and salt reduction policies should continue to be monitored.

\section{Introduction}

Overweight and obesity are nowadays a major global public health problem as more than 1.9 billion adults were overweight and 650 million obese in 2016 worldwide [1]. In the framework of the epidemiological and nutrition transition, overweight, obesity and associated non-communicable diseases have increased especially rapidly in the low- and middle-income countries (LMICs), including the Middle East and North Africa (MENA) region where the prevalence of obesity and diabetes are among the highest worldwide [2]. Nevertheless, the rapid changes in lifestyles underlying the nutrition transition, including towards westernized and more energy rich diets have not always been exclusive of the persistence of micronutrient deficiencies [3]. This has resulted in some contexts, in a double burden of malnutrition resulting from the co-existence of excess adiposity and/or associated Noncommunicable diseases (NCDs) and undernutrition phenomena partly linked to micronutrient deficiencies, e.g. as documented for iron deficiency and anaemia [4-6].

As for micronutrient deficiencies, iodine deficiency (ID) is one of the most prevalent in the world at the rate of $27.8 \%$ or two billion of people in the general population [7]. In order to tackle ID, a number of countries, including the MENA region, have adopted universal salt iodization (USI) programme [7]. This USI programme achieved some success in reducing ID, in certain contexts ([8]), but defaults in the process of salt iodization, were also sometimes shown to increase the risk of iodine excess (IE) [7, 9]. Also, in the context of the nutrition transition, the salt-rich westernized diet which underlies the progression of excess adiposity in LMICs, could result in a cumulative effect with respect to iodine status [10]. Beyond, at the metabolic level, it also has been documented that iodine disturbances with consequences on thyroid function (hyfonction), can occur among obese subjects [11-13]. Although the links are not completely elucidated [14], it is possible that this association may be complicated in the framework of inadequate iodine status either deficiency or excess. In such nutrition transition context, it seems of interest to address the issue of the double burden of excess adiposity and iodine inadequate status. Double burden of over and under nutrition can arise from their co-occurrence at different aggregated levels, i.e. in different sub-populations in the same geographical area, or among different members within the same households [15]. But it is all the more an issue when both adverse conditions co-occur within the same subjects [4, 5]. Without strong hypotheses pertaining to independent co-occurrence of both conditions in the same subjects, assessing such a within-subject double burden necessitates all the relevant data on the same individuals. From a practical point of view, the monitoring of USI programme is mostly based on survey pertaining to 6-12 y., school-age children which is the internationally recommended target age class for the assessment of iodine status in populations [16]. Yet, this age class has not been spared from the worldwide progression of overweight and obesity, including the MENA region [14].

Tunisia is a typical MENA country undergoing the nutrition transition, featuring high prevalences of overweight and obesity including among children [17]. Also, a national survey among 6-12 y. to monitor the USI programme launched in 1995, documented that if only one in ten children featured ID, more than half were at risk of iodine excess [18].

Based on this national sample of 6-12 y. children in Tunisia, the objectives of the study were then to assess: - the magnitude of the within-subject cooccurrence of excess adiposity and inadequate iodine status, - the nature of that co-occurrence (independent, synergetic or antagonistic), - and the association with socio-demographic factors.

\section{Methods}

\section{Study area}

Tunisia is a North African country, located between Algeria at west and Libya at east, with about eleven million inhabitants of which two thirds are urban. It is ranked 95th out of 189 countries (i.e. at the lower end of the high development group of countries), according to the Human Development Index [19]. The level of economic development is much higher in the northern and eastern coastal regions, than in the mountainous western inland parts, especially the north- and central-west regions, or the mainly desert south-west. Due to the epidemiological and nutrition transition it has experienced in the last decades, Tunisia

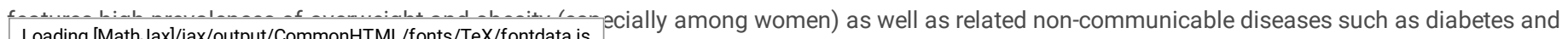


hypertension $[4,5,20,21]$. As for control of iodine deficiency, mandatory salt iodization had been implemented in specific areas since 1984 , but the national USI program was adopted in 1995 and launched in 1996 [18, 22]. Its evaluation in 2012 showed some success regarding control of iodine deficiency, but also a high proportion of excess iodine intake, partly in relation with defaults in the salt iodization process and its monitoring [22].

\section{Participants}

The present study is a based on a secondary analysis of data collected in a previously documented national cross-sectional survey conducted in Tunisia between May and June 2012: 6-12 y. school-children $(n=1560)$ were surveyed using a random, stratified, clustered sample [18].

\section{Measurements}

\section{Anthropometry}

Anthropometric assessment was performed according to the World Health Organization (WHO) standards [23]. Height was measured using a wall-mounted stadiometer (Person-check®, Kirchner and Wilhelm, Germany) with a precision of $0.1 \mathrm{~cm}$. Weight was measured using a calibrated scale (Detecto, Webb City, MO, USA. BMI (Body Mass Index = weight/height ${ }^{2}$ ) for-age in z-scores was computed from the WHO reference for school-age children. Thinness was defined as BMI-for-age $<-2$ z-scores, overweight as BMI-for-age $\geq+1 \mathrm{z}$ and obesity as BMI-for-age $\geq+2 \mathrm{z}$.

\section{lodine status}

Urine samples were collected according to standardized procedures [24]. The Sandell-Kholthoff method was used to assess urinary iodine concentration (UIC) [16]. Details related to technique precision and validation were previously published [18]. The WHO cut-offs for assessment of population iodine status based on the median UIC ( $\mu \mathrm{g} / \mathrm{L})$ were used to classify school-age children as follow [16, 25]: UIC < 100 defined iodine deficiency (ID), UIC $\geq 200$ defined iodine intake above requirements $\left(\mathrm{IAR}_{200}\right)$ and $\mathrm{UIC} \geq 300$ defined excess of iodine status $\left(\mathrm{IE}_{300}\right)$.

\section{Co-occurrence of inadequate iodine and anthropometric status}

Nine different co-occurrences were studied: ID and overweight (or obesity or thinness), IAR 200 and overweight (or obesity or thinness), IE $\mathrm{E}_{300}$ and overweight (or obesity or thinness), (Table 1).

Table 1

Prevalence of the co-occurrence of inadequate iodine status and thinness or excess adiposity among 6-12 y. Tunisian school children, by sex.

\begin{tabular}{|c|c|c|c|c|c|c|c|c|c|}
\hline & & \multicolumn{2}{|c|}{ All $(n=1560)$} & \multicolumn{6}{|c|}{$\begin{array}{l}\text { Co-occurrence of } \\
\text { inadequate iodine and BMI status }\end{array}$} \\
\hline & & $\begin{array}{l}\text { lodine } \\
\text { status }\end{array}$ & BMI status & \multicolumn{2}{|c|}{ All $(n=1560)$} & & Girls $(n=780)$ & Boys $(n=780)$ & \multirow[t]{2}{*}{$P$-Value ${ }^{\mathrm{d}}$} \\
\hline & & $\%^{a}$ & $\%^{a}$ & $\%^{a}$ & $95 \% \mathrm{Cl}^{\mathrm{b}}$ & P-Value ${ }^{c}$ & $\%^{a}$ & $\%^{a}$ & \\
\hline \multirow[t]{3}{*}{$\mathrm{ID}^{\mathrm{e}}$} & Thinness $^{f}$ & 11.4 & 7.0 & 0.7 & $0.3-1.3$ & 0.54 & 0.6 & 0.7 & 0.96 \\
\hline & Overweight $^{f}$ & & 18.4 & 2.5 & $1.3-4.8$ & 0.48 & 2.2 & 2.9 & 0.46 \\
\hline & Obesity $^{f}$ & & 6.4 & 1.0 & $0.5-2.1$ & 0.30 & 0.6 & 1.5 & 0.28 \\
\hline \multirow[t]{3}{*}{$\mid A R_{200}{ }^{e}$} & Thinness $^{f}$ & 52.2 & 7.0 & 4.1 & $2.9-5.6$ & 0.63 & 4.0 & 4.2 & 0.87 \\
\hline & Overweight $^{f}$ & & 18.4 & 9.7 & $7.7-12.3$ & 0.29 & 9.1 & 10.4 & 0.53 \\
\hline & Obesity $^{f}$ & & 6.4 & 3.2 & $2.0-5.5$ & 0.43 & 3.9 & 2.4 & 0.17 \\
\hline \multirow[t]{3}{*}{$\mathrm{IE}_{300} \mathrm{e}^{\mathrm{e}}$} & Thinness $^{f}$ & 25.1 & 7.0 & 1.7 & $1.1-2.4$ & 0.74 & 1.4 & 2.0 & 0.37 \\
\hline & Overweight $^{f}$ & & 18.4 & 5.0 & $3.7-6.7$ & 0.32 & 4.9 & 5.1 & 0.89 \\
\hline & Obesity ${ }^{f}$ & & 6.4 & 1.8 & $1.1-2.8$ & 0.48 & 2.2 & 1.4 & 0.35 \\
\hline
\end{tabular}

a Weighted percentage

b $95 \%$ confidence interval taking into account the complex sampling design.

${ }^{\mathrm{c}}$ Chi-square test of null hypothesis of independence between inadequate iodine status and inadequate BMI status

${ }^{d}$ Chisquare test for comparaison of $\%$ among girls vs. boys.

$e^{e} I D$ : lodine deficiency (UIC $<100 \mu \mathrm{g} / \mathrm{L}$ ), IAR 200 lodine Above Requirements (UIC $\geq 200 \mu \mathrm{g} / \mathrm{L}$ ), IE 300 lodine excess (UIC $\geq 300 \mu \mathrm{g} / \mathrm{L}$ ).

f Thinnecc. RMl-fnr-ane <-2 7-cenre nverwainht. RMl-fnr-age $\geq+1$ z-score, obesity: BMl-for-age $\geq+2$ z-score

Loading [MathJax]/jax/output/CommonHTML/fonts/TeX/fontdata.js

Page 3/11 
Each double burden was coded as a categorical variable with four categories, e.g. for "iodine intake above requirements (UIC $\geq 200)$ and overweight": iodine intake above requirements and overweight $\left(I A R_{200} \& O W\right)$, iodine intake above requirements and not overweight ( $\left.I A R_{200} \& O W\right)$, no iodine intake above requirements and overweight $\left(I_{A} \bar{R}_{200} \& O W\right)$, no iodine intake above requirements and no overweight $\left(I_{200} \& \bar{R}_{20}\right)$.

\section{Socio-demographic characteristics}

A self-administered questionnaire was used to collect information on the parent's occupation, instruction level and age.

\section{Statistical analysis}

Data management and statistical analyses were carried out with Stata software (version 14.0; StataCorp, College Station, USA). The type I error risk was set at 0.05 for all analyses. All estimates, standard errors, P-values and confidence intervals take into account the complex sampling plan (svy prefix in Stata).

Descriptive results are expressed as means for interval variables, and as proportions for categorical variables. For each of the nine combinations of iodine $x$ anthropometric status, the null hypothesis of independence between the iodine and anthropometric status binary variables was assessed using chi-square tests. Associations between the double burdens in four categories and socio-demographic factors were quantified by relative prevalence ratios (RPR) estimated within multinomial logistic regression models using the mlogit Stata command [26]: the response reference category was that of both not

inadequate iodine and no excess adiposity (e.g. for the "lodine Above Requirements and Overweight" double burden, this was the $I A \bar{R}_{200} \& \bar{O}_{W}$ category). This analysis, using double burdens coded as 4 category response variables, enabled to estimate associations with co-variates of single and double burdens from the same model ( $v$. the same response reference category i.e. subjects with none). For each covariable (milieu, region, sex, age, mother's and father's level of education and professional activity), crude associations were estimated in univariate models featuring one covariate at a time. Adjusted associations were derived from a multivariate model including all covariables.

Descriptive analyses were first performed separately for girls $v$. boys. But as we did not observe meaningful differences, multivariate analyses were ultimately ran and presented for girls and boys together.

\section{Results}

\section{Sample characteristics}

The population characteristics have been previously published [18]: 1560 school children were included in the study, and their mean age was $9.3 \pm 0.04 \mathrm{y}$. More than $90 \%$ of children's parents had attended at least primary school ( $94.6 \%$ for fathers $v s .86 .2 \%$ for mothers) and $94.3 \%$ of fathers but only $25.2 \%$ of mothers had a professional activity. Mean weight of the children was $30.4 \pm 0.4 \mathrm{~kg}$, mean height $134.3 \pm 0.5 \mathrm{~cm}$ and mean BMI $16.5 \pm 0.1 \mathrm{~kg} / \mathrm{m}^{2}(-0.18 \mathrm{z}$-scores \pm 0.06$)$. Prevalence of thinness was 7.0\% (95\% Cl: 5.6-8.7); 18.4\% (95\% Cl: 15.5-21.7) were overweight and 6.4\% (95\% Cl: 4.8-8.4) were obese (Table 1). Median UIC was $220 \mu \mathrm{g} / \mathrm{L}$, prevalence of ID was $11.4 \%$ (95\% Cl: 8.6-14.9), while $52.2 \%$ (95\% Cl: $50.1-62.2$ ) had UIC $\geq 200$ and $25.1 \%$ (95\% Cl: $19.6-31.4)$ featured UIC $\geq$ 300 (Table 1).

\section{Co-occurrence of inadequate iodine and anthropometric status}

There was no difference in prevalence between girls and boys, whatever the co-occurrence of inadequate iodine and anthropometric status considered (Table 1). The highest overall prevalence of double burden was observed for the co-occurrence of IAR 200 \& Ow at 9.7\% (95\%: 7.7-14.3). Also, 5.0\% (95\%: 3.76.7) of the children featured both $\mathrm{IE}_{300} \& \mathrm{Ow}$. Other types of inadequate iodine and anthropometric status double burdens were rare. Our data did not provide any evidence at the 0.05 alpha level against the null hypothesis of independence between inadequate iodine an anthropometric status, whatever the combination considered (P-value for chi-square tests ranging from 0.29 to 0.74 ).

\section{Association of the double burden with socio-demographic factors}

The reported results are relative only to the study of the iodine intake above requirements $(U I C \geq 200)$ - overweight double burden due to the low rate of the other forms (Table 2). 
Table 2

Multinomial regression: crude or adjusted associations between the categories of the "iodine above requirements (UIC $\geq 200 \mu \mathrm{g} / \mathrm{L})$ and overweight" double bul and socio-demographic factors among 6-12 y. Tunisian school children.

\begin{tabular}{|c|c|c|c|c|c|c|c|c|c|c|c|c|c|c|c|c|}
\hline & \multirow[b]{3}{*}{$\mathbf{n}$} & \multicolumn{5}{|c|}{ UIC $\geq 200 \mu \mathrm{g} / \mathrm{L} \&$ not overweight } & \multicolumn{5}{|c|}{ UIC $<200 \mu \mathrm{g} / \mathrm{L} \&$ overweight } & \multicolumn{5}{|c|}{ UIC $\geq 200 \mu \mathrm{g} / \mathrm{L} \&$ overweight } \\
\hline & & \multicolumn{3}{|c|}{ Crude } & \multicolumn{2}{|c|}{ Adjusted } & \multicolumn{3}{|c|}{ Crude } & \multicolumn{2}{|c|}{ Adjusted } & \multicolumn{3}{|c|}{ Crude } & \multicolumn{2}{|c|}{ Adjusted } \\
\hline & & $\%^{a}$ & $\mathrm{RPR}^{\mathrm{b}}$ & C.I. ${ }^{c}$ & $\mathrm{RPR}^{\mathrm{b}}$ & C.I. ${ }^{c}$ & $\%^{a}$ & RPR $^{\mathrm{d}}$ & C.I. ${ }^{c}$ & RPR $^{d}$ & C.I. ${ }^{\mathrm{c}}$ & $\%^{a}$ & $\mathrm{RPR}^{\mathrm{e}}$ & C.I. ${ }^{c}$ & RPR & C. \\
\hline Sex & & & \multicolumn{2}{|c|}{$\mathrm{P}^{\mathrm{f}}=0.001$} & \multicolumn{2}{|c|}{$\mathrm{P}^{\mathrm{f}}=0.0011$} & & \multicolumn{2}{|c|}{$\mathrm{P}^{\mathrm{g}}=0.12$} & \multicolumn{2}{|c|}{$\mathrm{P}^{\mathrm{g}}=\mathbf{0} .0 .046$} & & \multicolumn{2}{|c|}{$\mathrm{P}^{\mathrm{h}}=0.73$} & \multicolumn{2}{|c|}{$P^{h}=0.60$} \\
\hline Boy & 780 & 52.8 & 1 & - & 1 & - & 6.5 & 1 & - & 1 & - & 9.1 & 1 & - & 1 & - \\
\hline girl & 780 & 39.6 & 0.6 & $\begin{array}{l}0.4- \\
0.8\end{array}$ & 0.6 & $\begin{array}{l}0.4- \\
0.8\end{array}$ & 11.0 & 1.4 & $\begin{array}{l}0.3- \\
2.0\end{array}$ & 1.5 & $\begin{array}{l}1.0- \\
2.2\end{array}$ & 10.4 & 0.9 & $\begin{array}{l}0.5- \\
1.5\end{array}$ & 0.9 & $\begin{array}{l}0 . \\
1 .\end{array}$ \\
\hline Age (years) & & & \multicolumn{2}{|c|}{$P=0.41$} & \multicolumn{2}{|c|}{$P=0.39$} & & \multicolumn{2}{|c|}{$P=0.42$} & \multicolumn{2}{|c|}{$P=0.21$} & & \multicolumn{2}{|c|}{$P=0.23$} & \multicolumn{2}{|c|}{$P=0.21$} \\
\hline $6-7$ & 441 & 51.2 & 1 & - & 1 & - & 7.0 & 1 & - & 1 & - & 7.1 & 1 & - & 1 & - \\
\hline $8-9$ & 537 & 44.9 & 0.8 & $\begin{array}{l}0.6- \\
1.1\end{array}$ & 0.8 & $\begin{array}{l}0.6- \\
1.1\end{array}$ & 9.6 & 1.3 & $\begin{array}{l}0.9- \\
2.0\end{array}$ & 1.5 & $\begin{array}{l}0.9- \\
2.5\end{array}$ & 9.3 & 1.2 & $\begin{array}{l}0.6- \\
2.4\end{array}$ & 1.4 & $\begin{array}{l}0 . \\
2 .\end{array}$ \\
\hline $10-12$ & 582 & 44.4 & 0.9 & $\begin{array}{l}0.6- \\
1.2\end{array}$ & 0.8 & $\begin{array}{l}0.6^{-} \\
1.1\end{array}$ & 9.0 & 1.3 & $\begin{array}{l}0.6- \\
2.7\end{array}$ & 1.5 & $\begin{array}{l}0.7- \\
3.1\end{array}$ & 12.2 & 1.7 & $\begin{array}{l}0.8- \\
3.7\end{array}$ & 1.9 & $\begin{array}{l}0 . \\
4 .\end{array}$ \\
\hline Milieu & & & \multicolumn{2}{|c|}{$P=0.66$} & \multicolumn{2}{|c|}{$P=0.96$} & & \multicolumn{2}{|c|}{$P=0.009$} & \multicolumn{2}{|c|}{$P=0.71$} & & \multicolumn{2}{|c|}{$P=0.007$} & \multicolumn{2}{|c|}{$P=0.16$} \\
\hline Urban & 858 & 45.4 & 1 & - & 1 & - & 10.4 & 1 & - & 1 & - & 11.7 & 1 & - & 1 & - \\
\hline Rural & 702 & 48.4 & 0.9 & $\begin{array}{l}0.4- \\
1.7\end{array}$ & 1.0 & $\begin{array}{l}0.6^{-} \\
1.6\end{array}$ & 5.5 & 0.4 & $\begin{array}{l}0.2- \\
0.8\end{array}$ & 0.9 & $\begin{array}{l}0.6- \\
1.5\end{array}$ & 6.2 & 0.4 & $\begin{array}{l}0.2- \\
0.8\end{array}$ & 0.7 & $\begin{array}{l}0 . \\
1 .\end{array}$ \\
\hline Region & & & \multicolumn{2}{|c|}{$P<0.0001$} & \multicolumn{2}{|c|}{$P<0.0001$} & & $P=0$. & & $P=0.2$ & & & $P<0$ & 001 & $\mathrm{P}<0$ & 001 \\
\hline Greater Tunis & 240 & 50.6 & 1 & - & 1 & - & 11.4 & 1 & - & 1 & - & 11.4 & 1 & - & 1 & - \\
\hline North East & 180 & 24.3 & 0.2 & $\begin{array}{l}0.1- \\
0.6\end{array}$ & 0.2 & $\begin{array}{l}0.1- \\
0.6\end{array}$ & 18.1 & 0.8 & $\begin{array}{l}0.5- \\
1.2\end{array}$ & 1.0 & $\begin{array}{l}0.6- \\
1.6\end{array}$ & 5.2 & 0.2 & $\begin{array}{l}0.1- \\
0.9\end{array}$ & 0.3 & $\begin{array}{l}0 . \\
1 .\end{array}$ \\
\hline North West & 360 & 46.8 & 0.6 & $\begin{array}{l}0.3- \\
1.3\end{array}$ & 0.6 & $\begin{array}{l}0.3- \\
1.4\end{array}$ & 6.1 & 0.3 & $\begin{array}{l}0.2- \\
0.7\end{array}$ & 0.5 & $\begin{array}{l}0.2- \\
1.2\end{array}$ & 7.1 & 0.4 & $\begin{array}{l}0.2- \\
0.7\end{array}$ & 0.6 & $\begin{array}{l}0 . \\
1 .\end{array}$ \\
\hline Centre East & 240 & 40.6 & 0.5 & $\begin{array}{l}0.2- \\
1.3\end{array}$ & 0.5 & $\begin{array}{l}0.2- \\
1.4\end{array}$ & 8.5 & 0.5 & $\begin{array}{l}0.2- \\
0.9\end{array}$ & 0.5 & $\begin{array}{l}0.2- \\
1.2\end{array}$ & 9.9 & 0.6 & $\begin{array}{l}0.2- \\
1.4\end{array}$ & 0.7 & $\begin{array}{l}0 . \\
1 .\end{array}$ \\
\hline Centre West & 180 & 52.5 & 0.8 & $\begin{array}{l}0.3- \\
2.2\end{array}$ & 0.8 & $\begin{array}{l}0.3- \\
2.2\end{array}$ & 3.0 & 0.2 & $\begin{array}{l}0.1- \\
0.5\end{array}$ & 0.3 & $\begin{array}{l}0.1- \\
0.8\end{array}$ & 8.2 & 0.5 & $\begin{array}{l}0.2- \\
1.3\end{array}$ & 0.9 & $\begin{array}{l}0 . \\
2 .\end{array}$ \\
\hline South East & 180 & 67.2 & 2.5 & $\begin{array}{l}1.2- \\
5.3\end{array}$ & 2.7 & $\begin{array}{l}1.2- \\
6.0\end{array}$ & 3.0 & 0.5 & $\begin{array}{l}0.3- \\
0.8\end{array}$ & 0.6 & $\begin{array}{l}0.3- \\
1.2\end{array}$ & 15.9 & 2.6 & $\begin{array}{l}1.8- \\
3.9\end{array}$ & 3.6 & 2. \\
\hline South West & 180 & 60.5 & 1.7 & $\begin{array}{l}0.7- \\
3.7\end{array}$ & 1.7 & $\begin{array}{l}0.7- \\
3.8\end{array}$ & 6.9 & 0.8 & $\begin{array}{l}0.3- \\
2.7\end{array}$ & 0.9 & $\begin{array}{l}0.3- \\
2.3\end{array}$ & 13.7 & 1.7 & $\begin{array}{l}0.4- \\
7.5\end{array}$ & 1.9 & $\begin{array}{l}0 . \\
5 .\end{array}$ \\
\hline
\end{tabular}

Education of the

father

\begin{tabular}{|c|c|c|c|c|c|c|c|c|c|c|c|c|c|c|c|c|}
\hline \multirow[b]{2}{*}{$\begin{array}{l}\text { No formal } \\
\text { schooling }\end{array}$} & \multirow[b]{2}{*}{92} & \multirow[b]{2}{*}{52.7} & \multicolumn{2}{|c|}{$P=0.88$} & \multicolumn{3}{|c|}{$P=0.55$} & \multicolumn{2}{|c|}{$P<0.0001$} & \multicolumn{3}{|c|}{$P=0.31$} & \multicolumn{2}{|c|}{$P=0.29$} & \multicolumn{2}{|c|}{$P=0.06$} \\
\hline & & & 1.1 & $\begin{array}{l}0.5- \\
2.2\end{array}$ & 1.4 & $\begin{array}{l}0.7- \\
2.7\end{array}$ & 1.3 & 0.1 & $\begin{array}{l}0.02- \\
0.5\end{array}$ & 0.3 & $\begin{array}{l}0.1- \\
1.5\end{array}$ & 9.9 & 0.8 & $\begin{array}{l}0.3- \\
2.3\end{array}$ & 3.1 & $\begin{array}{l}1 . \\
8 .\end{array}$ \\
\hline $\begin{array}{l}\text { Primary } \\
\text { schooling }\end{array}$ & 648 & 47.8 & 0.9 & $\begin{array}{l}0.6- \\
1.4\end{array}$ & 1.1 & $\begin{array}{l}0.7- \\
1.8\end{array}$ & 6.0 & 0.4 & $\begin{array}{l}0.02- \\
0.5\end{array}$ & 0.9 & $\begin{array}{l}0.5- \\
1.5\end{array}$ & 8.2 & 0.6 & $\begin{array}{l}0.3- \\
1.3\end{array}$ & 1.2 & $\begin{array}{l}0 . \\
2 .\end{array}$ \\
\hline $\begin{array}{l}\text { Secondary and } \\
\text { more }\end{array}$ & 820 & 44.9 & 1 & - & 1 & - & 11.4 & 1 & - & 1 & - & 10.9 & 1 & - & 1 & - \\
\hline
\end{tabular}

Education of the

mother

\begin{tabular}{|c|c|c|c|c|c|c|c|c|c|c|c|c|c|c|c|c|}
\hline & & & \multicolumn{2}{|c|}{$P=0.17$} & \multicolumn{3}{|c|}{$P=0.42$} & \multicolumn{2}{|c|}{$P<0.0001$} & \multicolumn{3}{|c|}{$P=0.0002$} & \multicolumn{2}{|c|}{$P=0.0002$} & \multicolumn{2}{|c|}{$P=0.0021$} \\
\hline $\begin{array}{l}\text { No formal } \\
\text { schooling }\end{array}$ & 236 & 54.2 & 1.0 & $\begin{array}{l}0.6- \\
1.8\end{array}$ & 1.0 & $\begin{array}{l}0.7- \\
1.5\end{array}$ & 3.9 & 0.2 & $\begin{array}{l}0.1- \\
0.5\end{array}$ & 0.5 & $\begin{array}{l}0.2- \\
1.1\end{array}$ & 4.6 & 0.3 & $\begin{array}{l}0.1- \\
0.5\end{array}$ & 0.2 & $\begin{array}{l}0 . \\
0 .\end{array}$ \\
\hline $\begin{array}{l}\text { Primary } \\
\text { schooling }\end{array}$ & 648 & 47.3 & 0.8 & $\begin{array}{l}0.6- \\
1.1\end{array}$ & 0.8 & $\begin{array}{l}0.6- \\
1.1\end{array}$ & 5.1 & 0.3 & $\begin{array}{l}0.2- \\
0.4\end{array}$ & 0.4 & $\begin{array}{l}0.3- \\
0.6\end{array}$ & 7.4 & 0.4 & $\begin{array}{l}0.3- \\
0.7\end{array}$ & 0.4 & $\begin{array}{l}0 . \\
0 .\end{array}$ \\
\hline Secondary and & 676 & 43.6 & 1 & - & 1 & - & 13.0 & 1 & - & 1 & - & 13.1 & 1 & - & 1 & - \\
\hline
\end{tabular}

more

Occupation of

the father

Loading [MathJax]/jax/output/CommonHTML/fonts/TeX/fontdata.js 


\begin{tabular}{|c|c|c|c|c|c|c|c|c|c|c|c|c|c|c|c|c|}
\hline \multirow[b]{3}{*}{ Not working } & \multirow[b]{3}{*}{93} & \multicolumn{5}{|c|}{ UIC $\geq 200 \mu \mathrm{g} / \mathrm{L} \&$ not overweight } & \multicolumn{5}{|c|}{$\mathrm{UIC}<200 \mu \mathrm{g} / \mathrm{L} \&$ overweight } & \multicolumn{5}{|c|}{ UIC $\geq 200 \mu \mathrm{g} / \mathrm{L}$ \& overweight } \\
\hline & & & \multicolumn{2}{|c|}{$P=0.44$} & \multicolumn{2}{|c|}{$P=0.82$} & & \multicolumn{2}{|c|}{$P<0.0001$} & \multicolumn{2}{|c|}{$P=0.12$} & \multirow[b]{2}{*}{7.7} & \multicolumn{2}{|c|}{$P=0.31$} & \multicolumn{2}{|c|}{$P=0.90$} \\
\hline & & 44.9 & 0.9 & $\begin{array}{l}0.3- \\
3.3\end{array}$ & 0.8 & $\begin{array}{l}0.4- \\
2.0\end{array}$ & 13.9 & 0.9 & $\begin{array}{l}0.3- \\
3.2\end{array}$ & 1.8 & $\begin{array}{l}0.5- \\
6.9\end{array}$ & & 0.6 & $\begin{array}{l}0.2- \\
2.0\end{array}$ & 0.9 & $\begin{array}{l}0 . \\
1 .\end{array}$ \\
\hline Worker/employee & 1104 & 46.9 & 0.8 & $\begin{array}{l}0.6- \\
1.1\end{array}$ & 0.9 & $\begin{array}{l}0.6- \\
1.3\end{array}$ & 6.8 & 0.4 & $\begin{array}{l}0.3^{-} \\
0.6\end{array}$ & 0.7 & $\begin{array}{l}0.5- \\
1.1\end{array}$ & 9.1 & 0.6 & $\begin{array}{l}0.3- \\
1.2\end{array}$ & 0.7 & $\begin{array}{l}0 . \\
2 .\end{array}$ \\
\hline $\begin{array}{l}\text { Upper executive } \\
\text { employee }\end{array}$ & 363 & 40.7 & 0.4 & - & 1 & - & 15.6 & 1 & - & 1 & - & 12.5 & 1 & - & 1 & - \\
\hline \multicolumn{17}{|l|}{$\begin{array}{l}\text { Occupation of } \\
\text { the mother }\end{array}$} \\
\hline & & & \multicolumn{2}{|c|}{$P=0.71$} & \multicolumn{2}{|c|}{$P=0.63$} & & \multicolumn{2}{|c|}{$P=0.0007$} & \multicolumn{2}{|c|}{$P=0.32$} & & \multicolumn{2}{|c|}{$P=0.0001$} & \multicolumn{2}{|c|}{$P=0.09$} \\
\hline Not working & 1234 & 47.6 & 0.8 & $\begin{array}{l}0.5- \\
1.4\end{array}$ & 0.9 & $\begin{array}{l}0.6- \\
1.3\end{array}$ & 7.1 & 0.3 & $\begin{array}{l}0.2- \\
0.5\end{array}$ & 0.9 & $\begin{array}{l}0.6- \\
1.3\end{array}$ & 8.9 & 0.5 & $\begin{array}{l}0.3- \\
0.7\end{array}$ & 0.8 & $\begin{array}{l}0 . \\
1 .\end{array}$ \\
\hline Worker/employee & 181 & 43.8 & 0.9 & $\begin{array}{l}0.5- \\
1.3\end{array}$ & 1.1 & $\begin{array}{l}0.7- \\
1.7\end{array}$ & 10.3 & 0.5 & $\begin{array}{l}0.2- \\
1.1\end{array}$ & 1.1 & $\begin{array}{l}0.7- \\
1.7\end{array}$ & 13.7 & 0.8 & $\begin{array}{l}0.4- \\
1.9\end{array}$ & 1.4 & $\begin{array}{l}0 . \\
3 .\end{array}$ \\
\hline $\begin{array}{l}\text { Upper executive } \\
\text { employee }\end{array}$ & 145 & 36.2 & 1 & - & 1 & - & 19.7 & 1 & - & 1 & - & 13.4 & 1 & - & 1 & - \\
\hline
\end{tabular}

aWeighted percentage (accounting for sampling design, including unequal probabilities of selection).

${ }^{\mathrm{b}}$ RPR: for category of cofactor vs. reference category (for which RPR $=1$ ), crude or adjusted Relative Prevalence Ratio of having the double burden of $I A R \&($ vs. $\overline{I A R \&} \bar{O} w$ category (base response category).

${ }^{\mathrm{c}}$ Confidence interval at $95 \%$ for crude or adjusted RPR.

d RPR: for category of cofactor vs. reference category (for which RPR $=1$ ), crude or adjusted Relative Prevalence Ratio of having the double burden of $I A R \&($ $\bar{A} \bar{A} \& \& \bar{O}$ category (base response category).

e RPR: for category of cofactor vs. reference category (for which RPR $=1$ ), crude or adjusted Relative Prevalence Ratio of having the double burden of $I \bar{A} R \& C$ vs. $\bar{A} \bar{A} R \& \bar{O} w$ category (base response category).

${ }^{\mathrm{f}}$ Crude or adjusted P-value for association of $I A R \& \bar{O} w$ with co-factor.

g Crude or adjusted P-value for association of $I \bar{A} R \& O W$ with co-factor.

${ }^{\text {h }}$ Crude or adjusted P-value for association of $I A R \& O W$ with co-factor.

Being a girl (adjusted RPR $=0.6 ; 95 \% \mathrm{Cl}$ : [0.4-0.8]) or living in the North-East region (adjusted RPR $=0.2 ; 95 \%$ Cl: [0.1-0.6]) appears to be a protective factor as regard the occurrence of $I A R_{200} \& O W$ while living in the South-East region (adjusted RPR $=2.7 ; 95 \% \mathrm{Cl}$ : [1.2-6.0]) appears to be a risk factor. Also, few associations were depicted for the single burden of $I A \bar{R}_{200} \& O W$ : girls were more prone vs. boys (adjusted RPR = 1.5; 95\% Cl: [1.0-2.2]) while subjects in the Centre-West region were less at risk (RPR $=0.3 ; 95 \% \mathrm{Cl}$ : [0.1-0.8]). No association was found between the co-occurrence of $I A R_{200} \& O W$, and age or gender. In crude analyses, children living in rural areas, the North-East and the North-West were less prone to $I A R_{200} \& O w$, however, these association did not stand after adjustment. Children living in the South-Eastern part of the country were more at risk (adjusted RPR = 3.6; 95\% Cl: [2.5-5.2]). A father with a low level of education increased the risk (adjusted RPR $=3.1 ; 95 \% \mathrm{Cl}$ : [1.1-8.5]) while the same educational level among mothers appears to be a protective factor (adjusted RPR $=0.2:$ : $95 \% \mathrm{Cl}:[0.1-0.5])$.

\section{Discussion}

In a nutrition transition context, where excess adiposity but also inadequate iodine intake is of concern among children, our original study assessed the prevalence and the associated factors of the different forms of the within-subject double burden of excess of adiposity and inadequate iodine status among Tunisian 6-12 y. children. We showed that the most prevalent form of such a double burden was the co-occurrence of IAR (UIC $\geq 200$ ) with overweight, which concerned one child out of ten. We also underlined that excess adiposity and the different types of inadequate iodine (ID, IAR and IE) status co-occurred independently.

As this study is to our knowledge the first to tackle that issue, comparisons are difficult. This prevalence is coherent with the observed significant prevalences of both iodine intake above requirements (one child out of two) and overweight (two children out of ten). Nevertheless, how the prevalence of the double burden derives from the prevalences of each single burden depends on whether their co-occurrence is synergistic (e.g. the probability of iodine intake above requirements increases if the child is overweight or vice versa), antagonistic (e.g. the probability of iodine intake above requirements decreases if the child is overweight and vice versa) or independent. In the present study, whatever the type of iodine inadequate status (i.e. deficiency or excess), our data were in Loading [MathJax]/jax/output/CommonHTML/fonts/TeX/fontdata.js 
accordance with the hypothesis of its independent co-existence with overweight. Beyond the observed prevalences, this also is consistent with the observed associations of the excess iodine and overweight double burden with the area of residence and socio-demographic characteristics: indeed in the case of probabilistic independence it can be shown that the measure of associations (RPR) of the double burden $I A R_{200} \& O W$ with the co-factors should be identical

(or at least close) to the product of the RPR for the single burden categories $I A R_{200} \& O{ }_{w}$ and $I A \bar{R}_{200} \& O w$ [15]. Nevertheless, there are several hypotheses that could be in favour of a non-independent co-occurrence of inadequate iodine status and overweight either at the physiological and environmental level.

As for the physiological level, several epidemiologic and clinical studies have examined links between thyroid function and obesity [11, 27-34]. A conceptual framework was elaborated in order to depict the different factors that could modulate the association between both tissues (in Additional file 1: Figure S1.) $[11,13,16,35-49]$. Thyroid is deeply involved in the regulation of energy expenditure, basal metabolism, regulate food intake and thermogenesis. Theoretically, the slowdown of thyroid activity (hypothyroidism) is believed to cause low metabolic rate, reduced gluconeogenesis, reduced liposis and hence promoting weight gain $[50,51]$. This hypothesis was consistent with the reported negative association between body mass index and thyroid hormones level $[28,30-32,52]$.

More than adequate iodine intake may increase subclinical hypothyroidism [53]. In fact, a recent research conducted by Shan and al. [54] reported that subclinical hypothyroidism prevalence was significantly higher among population having more than adequate iodine ( $22.6 \%$ vs. $12.7 \%$ for adequate iodine intake, $\mathrm{P}<0.01$ ). A meta-analysis reported a significant risk of hypothyroidism pertaining to iodine excess [55]. In the other hand, it is thought that hypothyroidism could be a consequence of obesity $[56,57]$. In fact, low chronic inflammation grade, typically observed in obese subjects, has been proposed to depress thyroid function $[11,32,58]$. The link seems to be ensured by the leptin and pro-inflammatory cytokines [59]. There are clear association between thyroid hypofunction and hyperleptinemia $[33,60]$. This raise of hyperleptinemia is showing to increase the secretion of the pro-inflammatory cytokines. The different links between thyroid function, leptin and obesity have been extensively reviewed by Duntas and colleagues [33]. lodine appeared to be an important link in a loop configuration characterizing the association between thyroid gland and fat tissue accumulation.

Beyond the physiological pathways discussed above, in the context of the nutrition transition that countries of the MENA region are experiencing, there are also external factors e.g. linked to the food environment that could increase the risk of both inadequate iodine status and excess adiposity at subject level. Generally, the nutrition transition is characterized by an increased intake of foods with a high sugar, fat and salt content, and Tunisia is no exception [10, 17, 61]. Indeed, several studies reported a very high salt consumption, from 11 to $14 \mathrm{~g} /$ day vs. the $5 \mathrm{~g} /$ day recommended. [62, 63]. Also, as part of a worldwide strategy to tackle iodine deficiency disorders [16], Tunisia has implemented a USI program since 1995 [18]. Failure in the program monitoring and control has resulted in inadequately iodized salt (as a quarter of the commercialized salt is excessively iodized) [22]. In a such a context subjects with diets with high sugar, fat and salt content which would make them more prone to excess adiposity, would also be more at risk of excess iodine (as a cumulative effect of high salt intake and inadequate salt iodization). So that would be in favour of a synergetic rather than independent co-occurrence. There could be also interactions with the metabolic pathways above, e.g. in relation with the interactions between thyroid function and adipose tissue.

Compared with all the elements in favour of a synergistic co-occurrence explained above, our observations (which are in accordance with the independence hypothesis) may be due to methodological limitations. As for measurements, urine spot measurements have known limitations for the assessment of iodine status at individual level and especially long-term high iodine intake [64]. Also, no data was available about thyroid function biomarkers (free thyroxin and thyroid stimulating hormone). We did not either estimate iodine intake e.g. by measuring dietary intake. More importantly, it could be that the metabolic pathways pertaining to the non-independent co-occurrence of iodine excess and excess adiposity (and/or their interactions with environmental factors) get fully activated only in the long term. So that they would not manifest themselves fully in this population of 6-12 y. children. Testing that hypothesis would require the same kind of data on the same subjects when they reach adulthood or at a least on a comparable sample of adults. So that the $6-12 \mathrm{y}$. age-class is a limitation of our study. Nevertheless, this is by recommendation of the WHO, as school age children are the target age class for assessment of iodine status [25].

Beyond assessing the nature of the co-occurrence of iodine status and excess adiposity (i.e. synergistic, antagonistic or independent), the study population of school-age children also has limitations regarding the assessment of the magnitude of the double burden in the whole population. Nevertheless, WHO also considers that iodine status of school-age children can be used as an approximative estimate of iodine status of the whole population [16]. Based on the assumption that iodine status and excess adiposity are co-occurring independently, one can then infer a rough estimate of the double burden by the product of our observed prevalence of iodine intake above requirements (about a half) and that of overweight among Tunisian adults (about two thirds) [61, 65]: so that about a third of Tunisian adults would be at risk of both iodine intake above requirements and overweight (and all the more for adult women which are much more prone to excess adiposity in this context). From the same reasoning one can infer that about one woman out of ten would also be affected by the cooccurrence of overweight and iodine deficiency. These estimates would be a lower bound if one takes into account that the co-occurrence of inadequate iodine status and excess adiposity is likely more synergistic than independent in older subjects (vs. our studied age-class for which our data was compatible with the independence hypothesis). But this estimated prevalence of subject-level co-occurrence of overweight and inadequate iodine intake are nevertheless significant from a public health point of view, especially with regards to intergenerational effects on risk of both chronic diseases and mental development [66] as we underlined they are higher among women which are much more prone to excess adiposity in the context.

\section{Conclusion}

In the MENA region, lifestyles which underly the increase in excess adiposity and associated NCDs include diets with possibly increased salt content. This may result in excess iodine intake, which may cluster with excess adiposity both due to these shared environmental factors and synergistic metabolic pathways. In this study of Tunisian children, this hypothesis was not shown to be true. While obesity and excess iodine intake were documented, little overlap was detected.

Loading [MathJax]/jax/output/CommonHTML/fonts/TeX/fontdata.js 
As the nutritional transition proceeds in the MENA region it would be useful to monitor the prevalent double burden of excess iodine intake and excess adiposity.

\section{List Of Abbreviations}

95\% Cl: : 95\% confidence interval; IAR: Intake Above Requirements; ID: Iodine Deficiency; IE: Iodine Excess; LMICs: Low- and Middle-Income Countries; MENA: Middle East and North Africa; NCDs : Non Communicable Diseases; RPR : Relative Prevalence Ratios; UIC : Urinary lodine Concentration; USI: universal salt iodization; WHO: World Health Organization.

\section{Declarations}

\section{Ethical Approval and Consent to participate}

This study was conducted according to the guidelines laid down in the Declaration of Helsinki and all procedures involving human subjects/patients were approved by the Ethics Committee on Human Research of the National Institute of Nutrition and Food Technology, and the Tunisian National Council of Statistics (visa n॰8/2012). Written informed consent was obtained from the parents of all the children included in the study.

Consent for publication: Not applicable.

Availability of supporting data: The datasets used and/or analysed during the current study are available from the corresponding author on reasonable request.

Competing interests: The authors declare no conflicts of interest.

Funding: The work was supported by the Tunisian National Institute of Nutrition and Food Technology of the Tunisian Ministry of Health and by grants from UNICEF Tunisia.

The manuscript was drafted while RD was visiting research fellow at NUTRIPASS Unit, IRD (French National Research Institute for Sustainable Development), Montpellier, France, in 2018 (grant IRD “Mobilité Sud-Nord”).

Acknowledgements: We would like to thank the laboratory technicians and the field teams for their hard work in carrying out the activities of the current survey. We would like to express our gratitude to all the participants in the current survey including school children, their families and the school directors.

Author's contributions: All authors conceived and designed the protocol, supervised the field survey. R.D. and P.T. performed data management and statistical analyses. All authors wrote the paper.

\section{Author's information:}

INNTA (National Institute of Nutrition and Food Technology), SURVEN (Nutrition Surveillance and Epidemiology in Tunisia) Research Laboratory, 11 Rue Jebel Lakhdar, bab Saadoun, 1007, Tunis, Tunisia;

Radhouene Doggui \& Jalila El Ati

University of Tunis El Manar, 2092 Tunis, Tunisia.

Radhouene Doggui \& Jalila El Ati

Laboratory Materials Molecules and Applications LR11ES22

Myriam El Ati-Hellal

IPEST, University of Carthage. B.P. 51 La Marsa - Tunis 2070, Tunisia.

Myriam El Ati-Hellal

IRD (French National Research Institute for Sustainable Development), NUTRIPASS Unit, IRD-Université de Montpellier-Montpellier SupAgro, 911, Av Agropolis, 34394, Montpellier Cedex 5, France.

Pierre Traissac

\section{References}

1. Abarca-Gómez L, Abdeen ZA, Hamid ZA, Abu-Rmeileh NM, Acosta-Cazares B, Acuin C, Adams RJ. Worldwide trends in body-mass index, underweight, overweight, and obesity from 1975 to 2016 : a pooled analysis of 2416 population-based measurement studies in 128.9 million children, adolescents, and adults. Lancet. 2017;390:2627-42.

2. Farrag NS, Cheskin LJ, Farag MK. A systematic review of childhood obesity in the Middle East and North Africa (MENA) region: Prevalence and risk

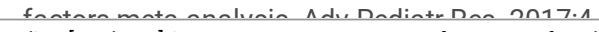


3. Popkin BM, Adair LS, Ng SW. Global nutrition transition and the pandemic of obesity in developing countries. Nutr Rev. 2012;70:3-21.

4. Gartner A, El Ati J, Traissac P, Bour A, Berger J, Landais E, El Hsaini H, Ben Rayana C, Delpeuch F. A double burden of overall or central adiposity and anemia or iron deficiency is prevalent but with little socioeconomic patterning among Moroccan and Tunisian urban women. J Nutr. 2014;144:87-97.

5. Traissac P, El Ati J, Gartner A, Ben Gharbia H, Delpeuch F. Gender inequalities in excess adiposity and anaemia combine in a large double burden of malnutrition gap detrimental to women in an urban area in North Africa. Public Health Nutr. 2016;19:1428-37.

6. Zeba AN, Delisle HF, Renier G, Savadogo B, Baya B. The double burden of malnutrition and cardiometabolic risk widens the gender and socio-economic health gap: a study among adults in Burkina Faso (West Africa). Public Health Nutr. 2012;15:2210-9.

7. Zimmermann MB, Andersson M. Update on iodine status worldwide. Curr Opin Endocrinol Diabetes Obes. 2012;19:382-7.

8. Azizi F, Sheikholeslam R, Hedayati M, Mirmiran P, Malekafzali H, Kimiagar M, Pajouhi M. Sustainable control of iodinedeficiency in Iran: beneficial results of the implementation of the mandatory law on salt iodization. J Endocrinol Invest. 2002;25:409-3.

9. Begin F, Codling K. lodized salt legislation in South and East Asia and the Pacific: an overview. IDD Newsletter. 2013;41:16.

10. Popkin BM. The nutrition transition in low-income countries: an emerging crisis. Nutr Rev. 1994;52:285-98.

11. Longhi S, Radetti G. Thyroid function and obesity. J Clin Res Pediatr Endocrinol. 2013;5 Suppl 1:40-4.

12. Sanyal D, Raychaudhuri M. Hypothyroidism and obesity: An intriguing link. Indian J Endocrinol Metab. 2016;20:554-7.

13. Witkowska-Sedek E, Kucharska A, Ruminska M, Pyrzak B. Thyroid dysfunction in obese and overweight children. Endokrynol Pol. 2017;68:54-60.

14. Feldt-Rasmussen U. Thyroid and leptin. Thyroid. 2007;17:413-9.

15. Sassi S, Abassi MM, Traissac P, Ben Gharbia H, Gartner A, Delpeuch F, El Ati J. Double burden of malnutrition among child-mother pairs in the North African nutrition transition context: Magnitude, and associated factors of the household-level co-occurrence of child anaemia and mother excess adiposity. Public Health Nutr. 2018.

16. WHO. lodine status worldwide. Geneva: World Health Organization; 2004.

17. Aounallah-Skhiri H, Traissac P, El Ati J, Eymard-Duvernay S, Landais E, Achour N, Delpeuch F, Ben Romdhane H, Maire B. Nutrition transition among adolescents of a south-Mediterranean country: dietary patterns, association with socio-economic factors, overweight and blood pressure. A crosssectional study in Tunisia. Nutr J. 2011;10:38.

18. Doggui R, El Ati-Hellal M, Traissac P, Lahmar L, El Ati J. Adequacy Assessment of a Universal Salt lodization Program Two Decades after Its Implementation: A National Cross-Sectional Study of lodine Status among School-Age Children in Tunisia. Nutrients. 2016;9.

19. UNDP. Briefing note for countries on the 2018 Statistical Update: Tunisia. New York, USA: United Nations Development Programme; 2018.

20. Ben Romdhane H, Ben Ali S, Skhiri H, Traissac P, Bougatef S, Maire B, Delpeuch F, Achour N. Hypertension among Tunisian adults: results of the TAHINA project. Hypertens Res. 2012;35:341-7.

21. Ben Romdhane H, Ben Ali S, Aissi W, Traissac P, Aounallah-Skhiri H, Bougatef S, Maire B, Delpeuch F, Achour N. Prevalence of diabetes in Northern African countries: the case of Tunisia. BMC Public Health. 2014;14:86.

22. Doggui R, El Ati-Hellal M, Traissac P, El Ati J. Unsatisfactory results of the Tunisian universal salt iodization program on national iodine levels. J Food Compost Anal. 2017;64:163-70.

23. de Onis M, Onyango AW, Borghi E, Siyam A, Nishida C, Siekmann J. Development of a WHO growth reference for school-aged children and adolescents. Bull World Health Organ. 2007;85:660-7.

24. Cornelis R, Heinzow B, Herber RF, Christensen JM, Poulsen OM, Sabbioni E, Templeton DM, Thomassen Y, Vahter M, Vesterberg O. Sample collection guidelines for trace elements in blood and urine. IUPAC Commission of Toxicology. J Trace Elem Med Biol. 1996;10:103-27.

25. WHO, UNICEF, ICCIDD. Assessment of iodine deficiency disorders and monitoring their elimination: a guide for programme managers. Geneva: :World Health Organization; 2007.

26. Hosmer DW. Lemeshow S. Applied logistic regression. New York. 2000.

27. Tagliaferri M, Berselli ME, Calo G, Minocci A, Savia G, Petroni ML, Viberti GC, Liuzzi A. Subclinical hypothyroidism in obese patients: relation to resting energy expenditure, serum leptin, body composition, and lipid profile. Obes Res. 2001;9:196-201.

28. Knudsen N, Laurberg P, Rasmussen LB, Bulow I, Perrild H, Ovesen L, Jorgensen T. Small differences in thyroid function may be important for body mass index and the occurrence of obesity in the population. J Clin Endocrinol Metab. 2005;90:4019-24.

29. Radetti G, Kleon W, Buzi F, Crivellaro C, Pappalardo L, di lorgi N, Maghnie M. Thyroid function and structure are affected in childhood obesity. J Clin Endocrinol Metab. 2008;93:4749-54.

30. Grandone A, Santoro N, Coppola F, Calabro P, Perrone L, Del Giudice EM. Thyroid function derangement and childhood obesity: an Italian experience. BMC Endocr Disord. 2010;10:8.

31. Marras V, Casini MR, Pilia S, Carta D, Civolani P, Porcu M, Uccheddu AP, Loche S. Thyroid function in obese children and adolescents. Horm Res Paediatr. 2010;73:193-7.

32. Chen H, Zhang H, Tang W, Xi Q, Liu X, Duan Y, Liu C. Thyroid function and morphology in overweight and obese children and adolescents in a Chinese population. J Pediatr Endocrinol Metab. 2013;26:489-96.

33. Duntas LH, Biondi B. The interconnections between obesity, thyroid function, and autoimmunity: the multifold role of leptin. Thyroid. 2013;23:646-53.

34. Mendez-Villa L, Garcia-Solis P, Solis SJ, Garcia-Gutierrez DG, Perez-Mora VA, Robles-Osorio L, Sampson-Zaldivar E. High lodine and Salt Intakes and Obesity do not Modify the Thyroid Function in Mexican Schoolchildren. Biol Trace Elem Res. 2016;172:290-8.

Loading [MathJax]/jax/output/CommonHTML/fonts/TeX/fontdata.js ne deficiency disorders revisited. Indian J Endocrinol Metab. 2010;14:13-7.

Page $9 / 11$ 
36. Zimmermann MB. Symposium on 'Geographical and geological influences on nutrition': lodine deficiency in industrialised countries. Proc Nutr Soc. 2010;69:133-43.

37. Ahima RS. Revisiting leptin's role in obesity and weight loss. J Clin Invest. 2008;118:2380-3.

38. Fried SK, Ricci MR, Russell CD, Laferrere B. Regulation of leptin production in humans. J Nutr. 2000;130:3127S-3131S.

39. Cohen S, Doyle WJ, Baum A. Socioeconomic status is associated with stress hormones. Psychosom Med. 2006;68:414-20.

40. Newton S, Braithwaite D, Akinyemiju TF. Socio-economic status over the life course and obesity: Systematic review and meta-analysis. PLoS One. 2017;12:e0177151.

41. Mu M, Xu LF, Hu D, Wu J, Bai MJ. Dietary Patterns and Overweight/Obesity: A Review Article. Iran J Public Health. 2017;46:869-76.

42. Cohen AK, Rai M, Rehkopf DH, Abrams B. Educational attainment and obesity: a systematic review. Obes Rev. 2013;14:989-1005.

43. Wiklund P. The role of physical activity and exercise in obesity and weight management: Time for critical appraisal. Journal of Sport and Health Science. 2016;5:151-4.

44. Kanaka-Gantenbein C. The impact of exercise on thyroid hormone metabolism in children and adolescents. Horm Metab Res. 2005;37:563-5.

45. Krajcovicova-Kudlackova M, Buckova K, Klimes I, Sebokova E. lodine deficiency in vegetarians and vegans. Ann Nutr Metab. 2003;47:183-5.

46. Tonstad S, Nathan E, Oda K, Fraser G. Vegan diets and hypothyroidism. Nutrients. 2013;5:4642-52.

47. Leung AM, Braverman LE. Consequences of excess iodine. Nat Rev Endocrinol. 2014;10:136-42.

48. Zimmermann MB, Aeberli I, Andersson M, Assey V, Yorg JA, Jooste P, Jukic T, Kartono D, Kusic Z, Pretell E, et al. Thyroglobulin is a sensitive measure of both deficient and excess iodine intakes in children and indicates no adverse effects on thyroid function in the UIC range of 100-299 mug/L: a UNICEF/ICCIDD study group report. J Clin Endocrinol Metab. 2013;98:1271-80.

49. WHO. Obesity: preventing and managing the global epidemic. Geneva: World Health Organization; 2000.

50. Hart I, Newton RW. Endocrinology. Netherlands: Springer; 2012.

51. Mullur R, Liu YY, Brent GA. Thyroid hormone regulation of metabolism. Physiol Rev. 2014;94:355-82.

52. Marwaha RK, Tandon N, Garg MK, Ganie MA, Narang A, Mehan N, Bhadra K. Impact of body mass index on thyroid functions in Indian children. Clin Endocrinol (Oxf). 2013;79:424-8.

53. Teng X, Shan Z, Chen Y, Lai Y, Yu J, Shan L, Bai X, Li Y, Li N, Li Z, et al. More than adequate iodine intake may increase subclinical hypothyroidism and autoimmune thyroiditis: a cross-sectional study based on two Chinese communities with different iodine intake levels. Eur J Endocrinol. 2011;164:943-50.

54. Shan Z, Chen L, Lian X, Liu C, Shi B, Shi L, Tong N, Wang S, Weng J, Zhao J, et al. lodine Status and Prevalence of Thyroid Disorders After Introduction of Mandatory Universal Salt lodization for 16 Years in China: A Cross-Sectional Study in 10 Cities. Thyroid. 2016;26:1125-30.

55. Katagiri R, Yuan X, Kobayashi S, Sasaki S. Effect of excess iodine intake on thyroid diseases in different populations: A systematic review and metaanalyses including observational studies. PLoS One. 2017;12:e0173722.

56. Salerno M, Capalbo D, Cerbone M, De Luca F. Subclinical hypothyroidism in childhood - current knowledge and open issues. Nat Rev Endocrinol. 2016;12:734-746.

57. Rotondi M, Magri F, Chiovato L. Thyroid and obesity: not a one-way interaction. J Clin Endocrinol Metab. 2011;96:344-6.

58. Ellulu MS, Patimah I, Khaza'ai H, Rahmat A, Abed Y. Obesity and inflammation: the linking mechanism and the complications. Arch Med Sci. 2017;13:85163.

59. García OP, Long KZ, Rosado JL. Impact of micronutrient deficiencies on obesity. Nutrition Reviews. 2009;67:559-72.

60. Hsieh CJ, Wang PW, Wang ST, Liu RT, Tung SC, Chien WY, Lu YC, Chen JF, Chen CH, Kuo MC. Serum leptin concentrations of patients with sequential thyroid function changes. Clin Endocrinol (Oxf). 2002;57:29-34.

61. Abassi MM, Sassi S, El Ati J, Ben Gharbia H, Delpeuch F, Traissac P. Gender inequalities in diet quality and their socioeconomic patterning in a nutrition transition context in the Middle East and North Africa: a cross-sectional study in Tunisia. Nutr J. 2019;18:18.

62. Mason H, Shoaibi A, Ghandour R, O'Flaherty M, Capewell S, Khatib R, Jabr S, Unal B, Sozmen K, Arfa C, et al. A cost effectiveness analysis of salt reduction policies to reduce coronary heart disease in four Eastern Mediterranean countries. PLoS One. 2014;9:e84445.

63. Al Jawaldeh A, Rafii B, Nasreddine L. Salt intake reduction strategies in the Eastern Mediterranean Region. Eastern Mediterranean Health Journal. 2018;10.26719/emhj.18.006.

64. Wainwright $P$, Cook P. The assessment of iodine status - populations, individuals and limitations. Ann Clin Biochem. 2019;56:7-14.

65. El Ati J, Traissac P, Delpeuch F, Aounallah-Skhiri H, Beji C, Eymard-Duvernay S, Bougatef S, Kolsteren P, Maire B, Ben Romdhane H. Gender obesity inequities are huge but differ greatly according to environment and socio-economics in a North African setting: a national cross-sectional study in Tunisia. PLoS One. 2012;7:e48153.

66. Eastman CJ, Zimmermann MB. The lodine Deficiency Disorders. [Updated 2018 Feb 6]. In: Feingold KR, Anawalt B, Boyce A, et al., editors. Endotext [Internet]. South Dartmouth (MA): MDText.com, Inc.; 2000. Available from: https://www.ncbi.nlm.nih.gov/books/NBK285556/

\section{Additional File}

Figure S1. Conceptual framework of factors influencing the co-occurrence of inadequate iodine status and excess of adiposity

\section{Sunnlementarv Files}


This is a list of supplementary files associated with this preprint. Click to download.

- Additionalfile.docx

Loading [MathJax]/jax/output/CommonHTML/fonts/TeX/fontdata.js 